\title{
Management of Distribution Programs "Non Cash Food Aid" In Rembang District
}

\author{
Melly Anggraeni $^{1}$, Hardi Warsono ${ }^{2}$, Ida Hayu Dwimawanti ${ }^{3}$ \\ Master of Public Administration Sciences, Faculty of Social Sciences and Political \\ Sciences, Diponegoro University \\ melleypalingsip@gmail.com
}

(Received: October 24-2020; Revised: November 24-2020; Published: December 31-2020)

\begin{abstract}
This study aims to analyze and describe the distribution management of BPNT Non-Cash Food Aid in Rembang Regency. The problem in this research is how the Management of Non-Cash Food Aid Distribution in Rembang Regency. This research use George Tery's theory with qualitative descriptive methods and data analysis techniques Milles and Huberman. The results showed that: there are still many people who have not received a welfare family card, there is no recent update of data regarding program beneficiaries. Another problem in management is the need for measurable and accurate planning and identification of potential beneficiary communities so that it is right on target and the need for periodic socialization to the community so that they understand the mechanism for distributing BPNT assistance, the lack of coordination between the implementing team at the district level to the village level so that there is errors in verifying the names of beneficiaries, and lack of supervision from program assistants, so that many findings of errors in the field in the distribution mechanism of Non-Cash Food Assistance
\end{abstract}

\section{Keywords: Program Management, Non-Cash Food Aid}

\section{INTRODUCTION}

World Bank (2000) defines poverty as, "poverty is pronounced deprivation in well-being" which means that poverty is the loss of welfare, while according to Bappenas (2004) defines poverty as a condition in which a person or group of people, men and women, does not able to fulfill their basic rights to maintain and develop a dignified life.

Rembang Regency is one of the seven districts in Central Java Province which has a percentage of poor people above $15 \%$ in 2018 or in the lowest seven ranks of 35 districts / cities in Central Java. More precisely, the percentage of poor people in Rembang Regency is $15.41 \%$, or around 97.4 thousand people. In 2019, there was indeed a decrease in the poor to $14.95 \%$ or around $0.46 \%$. When compared to the other 6 districts with the highest percentage of poor people, this decrease is relatively small. Because it only reduced the number of poor people to around 2.1 thousand people. This condition is the lowest reduction in the number of poor people compared to districts / cities in Central Java Province.

The Rembang Regency Government in order to reduce the percentage of poor people has issued Regional Regulation Number 5 of 2019 concerning Poverty Alleviation and Rembang Regent Regulation Number 28 of 2019 concerning Guidelines for the Formation of a Poverty Reduction Coordination Team in Rembang Regency. This Coordination Team has the task of coordinating poverty reduction and controlling the implementation of poverty alleviation activities in Rembang Regency.

One of the poverty alleviation activities currently underway is the Non-Cash Food Assistance Program. Non-Cash Food Assistance, hereinafter referred to as BPNT. BPNT is a policy of the Central Government in the form of non-cash food social assistance provided to Beneficiary 
Melly Anggraeni, Hardi Warsono, Ida Hayu Dwimawanti; Management of Distribution ... $\mid 483$

Families (KPM) every month through an electronic account and is only used to purchase foodstuffs in e-warongs in collaboration with banks. BPNT is a transformation of the Prosperous Rice (Rastra) subsidy policy with a model of providing assistance in the form of Rp. 110,000 per month to buy rice and / or eggs as regulated in Regulation of the Minister of Social Affairs of the Republic of Indonesia Number 11 of 2018 concerning Distribution of Non-Cash Food Assistance . The Regulation of the Minister of Social Affairs was formulated to create the distribution of social food assistance that is effective, right on target, right in quantity, on time and in encouraging financial inclusion.

Non-Cash Food Assistance or in short, BPNT in its management still encounters several obstacles in the field, so that the implementation of the Non-Cash Food Assistance program as a poverty alleviation policy in Rembang district has not been maximal in reducing or alleviating the poverty problem that surrounds Rembang district.

Problems in managing cash food assistance include automatic termination by the system and no account transfers from February to April 2019. This is because the KPM of beneficiary families who did not make transactions for 3 (three) consecutive months was enforced so that the cut system was enforced. off from the Central Government. This is as shown in table 1below:

\section{Table 1}

Implementation of Non-Cash Food Assistance by District in June 2019

\begin{tabular}{|c|c|c|c|c|c|c|c|}
\hline \multirow[b]{2}{*}{ NO } & \multirow{2}{*}{$\begin{array}{c}\text { SUB } \\
\text { DISTRICTS }\end{array}$} & \multirow{2}{*}{$\begin{array}{c}\text { KUOTA } \\
\text { KPM }\end{array}$} & \multicolumn{3}{|c|}{ at Rembang Regency } & \multirow[b]{2}{*}{$\begin{array}{c}\text { NUMBER } \\
\text { OF }\end{array}$} & \multirow[b]{2}{*}{$\begin{array}{c}\text { TOT } \\
\text { AL }\end{array}$} \\
\hline & & & $\begin{array}{c}\text { KPM } \\
\text { TRANSACTION }\end{array}$ & $\begin{array}{r}\text { KPN } \\
\text { TRANS }\end{array}$ & & & \\
\hline & & & & TOTAL & $\%$ & $\begin{array}{c}\text { PROPOSED } \\
\text { REGIONAL } \\
\text { AGENTS }\end{array}$ & EDC \\
\hline
\end{tabular}

\begin{tabular}{rlrrrrrr}
\hline 1 & BULU & 3.683 & 3.363 & 320 & 8,69 & 21 & 20 \\
\hline 2 & GUNEM & 3.087 & 2.751 & 336 & 10,88 & 19 & 16 \\
\hline 3 & KALIORI & 4.579 & 3.900 & 679 & 14,83 & 26 & 18 \\
\hline 4 & KRAGAN & 7.745 & 6.814 & 931 & 12,02 & 41 & 30 \\
\hline 5 & LASEM & 4.665 & 3.581 & 1.084 & 23,24 & 28 & 24 \\
\hline 6 & PAMOTAN & 6.667 & 5.894 & 773 & 11,59 & 39 & 29 \\
\hline 7 & PANCUR & 4.333 & 4.107 & 226 & 5,22 & 29 & 26 \\
\hline 8 & REMBANG & 5.378 & 4.626 & 752 & 13,98 & 38 & 24 \\
\hline 9 & SALE & 3.362 & 3.175 & 187 & 5,56 & 20 & 16 \\
\hline 10 & SARANG & 7.078 & 6.631 & 447 & 6,32 & 35 & 14 \\
\hline 11 & SEDAN & 7.488 & 7.294 & 194 & 2,59 & 40 & 29 \\
\hline 12 & SLUKE & 3.638 & 3.287 & 351 & 9,65 & 20 & 17 \\
\hline 13 & SULANG & 4.516 & 4.131 & 385 & 8,53 & 25 & 19 \\
\hline 14 & SUMBER & 4.785 & 4.349 & 436 & 9,11 & 27 & 22 \\
\hline TOTAL & $\mathbf{7 1 . 0 0 4}$ & $\mathbf{6 3 . 9 0 3}$ & $\mathbf{7 . 1 0 1}$ & $\mathbf{1 0 , 0 0}$ & $\mathbf{4 0 8}$ & $\mathbf{3 0 4}$ \\
\hline
\end{tabular}

Source: Social Service, Women Empowerment and Family Planning Kab. Rembang 


\section{Jurnal Ilmiah Ilmu Administrasi Publik: Jurnal Pemikiran dan Penelitian Administrasi Publik \\ Volume 1o Number 2, July-December 2020. Page 482-488}

Data from the Office of Social Affairs, Women's Empowerment and Family Planning in Rembang Regency explains that the quota of Non-Cash Food Assistance Beneficiaries (KPM) in June 2019 was 71,004 KPM, but of this total only 63,903 KPM or $90.00 \%$ had already received a Prosperous Family Card (KKS) and made transactions in E-warong while 7,101 families or as much as $10.00 \%$ had not received a Prosperous Family Card (KKS) and had not made transactions as a condition for taking BPNT. The causes of the non-distribution of KKS include duplicate data, a single KPM candidate dies, a KPM candidate does not want to take it, a KPM candidate resigns because he is a well-off family, moves to another Regency / City, an unknown KPM candidate, an unprinted KKS and KKS has not been activated by the channeling bank.

Another problem is the number of E-warongs in Rembang Regency as many as 408 agents, but only 304 agents have been facilitated by EDC machines. Agents who have not yet received an EDC machine borrow from other agents to make transactions but this makes the distribution time longer, resulting in a decrease in the quality of food. From the problems mentioned above, it shows that the management of the Non-Cash Food Assistance program in Rembang Regency has not been maximized.

Based on the explanation of problems related to the management of the Non-Cash Food Assistance program. Researchers are interested in conducting an in-depth study regarding the management of the BNPT program for Non-Cash Food Assistance in Rembang Regency by using George R. Terry's theory of management functions in analyzing the problems that occur.

\section{METHOD}

This type of research is research with a qualitative approach, in which qualitative research is research with postpovite philosophy used on natural object conditions and the researcher is the key informant. A generalization so that process and meaning are always highlighted in the qualitative research process (Sugiyono, 2015). With the focus of this research is to analyze and describe the distribution management of the Non-Cash Food Aid Program in Rembang Regency. The data collection techniques in this study were interviews, observation and document study while the data analysis techniques were Miles and Huberman.

\section{RESULTS AND DISCUSSION}

\section{Planning for Management of Non-Cash Food Assistance in Rembang Regency}

Management in the organization is directed to achieve organizational goals effectively and efficiently. According to Syafaruddin (2011: 16) management is a process of working together between individuals and groups as well as other resources in achieving goals, organization is a management activity. In other words, managerial activities can only be found in the container of an organization, be it business organizations, schools and others. According to Hasibuan (2009: 198) management functions are basic elements that will always exist and are inherent in the management process which will be used as a reference by managers in carrying out activities to achieve goals. From the definition that has been described, the writer can conclude that management functions are a series of parts in management that must be used or applied so that the goals and vision and mission of the company can be achieved. 
Melly Anggraeni, Hardi Warsono, Ida Hayu Dwimawanti; Management of Distribution ... $\mid 485$

Planning is the activity of selecting and relating facts and making and using assumptions about the future in terms of visualizing and formulating proposed activities that are deemed necessary to achieve the desired results. From this definition, it can be concluded that planning is an activity of making sequences of actions to be carried out so that its objectives can be achieved. In planning, it must be able to answer six questions, namely: what to do, why should it be done, how it should be done, where it must be done and when it must be done. Because good planning will facilitate the process of the company's vision and mission that will be achieved by Siagian (2012: 36).

A thorough planning process in the management of Non-Cash Food Assistance must go through stages in planning such as 1). Setting goals, 2). Formulating the current state, 3). Identify the ease and obstacles, 4). Develop a series of activities. In the management of Non-Cash Food Assistance the planning system is returned to the Regional level by extending the assistance of the central government in verifying data on beneficiaries of the assistance and conducting socialization to the community of Rembang Regency.

The results of the study are related to the planning process of checking and verifying the names of beneficiary families that are not maximized so that there are still many poor families targeted by the BNPT program not receiving BNPT assistance. Lack of socialization of the Non-Cash Food Assistance program in Rembang Regency which should be carried out in stages, both in the form of coordination and consolidation with policy implementers as well as structurally up to the community as policy targets. So that many beneficiaries do not use the shared cocoa purchase card, this has an impact on systematic termination because the beneficiary family does not use the purchase cart for 3 three months consecutively.

Thus, it can be concluded that the planning process for the distribution of non-cash food aid needs to be planned and it is necessary to identify potential beneficiaries so that they are right on target and need regular outreach to the community so that they understand the mechanisms for distributing assistance.

\section{Actuating in Distribution of Non-Cash Food Aid in Rembang Regency.}

Actuating is an activity carried out by a manager / leader in influencing all group members, employees, employees who are able to strive to achieve what they want in accordance with what has been set in the planning of an organization. Anton Athilah (2010: 116) actuating is an activity that mobilizes and endeavors for workers in accordance with their unity and proportion to immediately carry out plans in concrete activities directed at predetermined goals, by always having communication, good human relations, effective leadership, provide motivation, make orders and instructions and morale for each group member. In actuating, there are the following:

a. determination of the initial time of implementation of the work plan.

b. Providing examples of procedures for implementing work from the leader.

c. Motivating workers to immediately work in accordance with their respective duties and responsibilities.

d. Communicating all work directions with all work units.

e. Development of workers.

f. Improve the quality and quality of work.

g. Supervision of work performance and morale 


\section{Jurnal Ilmiah Ilmu Administrasi Publik: Jurnal Pemikiran dan Penelitian Administrasi Publik \\ Volume 10 Number 2, July-December 2020. Page 482-488}

Actuating or mobilization is a stage that must be carried out by all parties in the management structure of the distribution of non-cash food aid in Rembang Regency, from the Social Service to the Village level.

Non-Cash Food Assistance in Rembang Regency was implemented on 30 (thirty) October 2018 which was strengthened by the Decree of the Rembang Regent Number 466/0671/2019 concerning the Formation of the Coordination Team for the Rembang Regency Non-Cash Food Assistance Program in 2019. This Non-Cash Food Aid is a transition from welfare rice social assistance (Bansos Rastra) to Non-Cash Food Assistance, but the distribution process of NonCash Food Aid as one of the poverty alleviation policies in Rembang Regency still has several problems. The problems that arise in actuating in this case are coordination in the distribution of BPNT, among others, as shown in table 2 below:

Table 2.

Implementation of Non-Cash Food Assistance by District in June 2019 in Rembang Regency

\begin{tabular}{|c|c|c|c|c|c|c|c|}
\hline \multirow[t]{2}{*}{ No. } & \multirow{2}{*}{$\begin{array}{l}\text { SUB- } \\
\text { DISTRICT }\end{array}$} & \multirow{2}{*}{$\begin{array}{l}\text { Quota } \\
\text { KPM }\end{array}$} & \multirow{2}{*}{$\begin{array}{l}\text { KPM } \\
\text { Transacti } \\
\text { on }\end{array}$} & \multicolumn{2}{|c|}{ KPM No Transaction } & \multirow{2}{*}{$\begin{array}{l}\text { Number of } \\
\text { Regional } \\
\text { Proposed } \\
\text { Agents }\end{array}$} & \multirow{2}{*}{$\begin{array}{l}\text { Amount } \\
\text { EDC }\end{array}$} \\
\hline & & & & amount & $\%$ & & \\
\hline 1. & Bulu & 3.683 & 3.363 & 320 & 8,69 & 21 & 20 \\
\hline 2. & Gunem & 3.087 & 2.751 & 336 & 10.88 & 19 & 16 \\
\hline 3. & Kaliori & 4.579 & 3.900 & 679 & 14.83 & 26 & 18 \\
\hline 4. & Krangan & 7.745 & 6.814 & 931 & 12,02 & 41 & 30 \\
\hline 5. & Lasem & 4.665 & 3.581 & 1.084 & 23,24 & 28 & 24 \\
\hline 6. & Pamotan & 6.667 & 5.894 & 773 & 11,59 & 39 & 29 \\
\hline 7. & Pancur & 4.333 & 4.107 & 226 & 5,22 & 29 & 26 \\
\hline 8. & Rembang & 5.378 & 4.626 & 752 & 13,98 & 38 & 24 \\
\hline 9. & Sale & 3.362 & 3.175 & 187 & 5,56 & 20 & 16 \\
\hline 10. & Sarang & 7.078 & 6.631 & 447 & 6,32 & 35 & 14 \\
\hline 11. & Sedan & 7.488 & 7.294 & 194 & 2,59 & 40 & 29 \\
\hline 12. & Sluke & 3.638 & 3.287 & 351 & 9,65 & 20 & 17 \\
\hline 13. & Sulang & 4.516 & 4.131 & 385 & 8,53 & 25 & 19 \\
\hline 14. & Sumber & 4.785 & 4.349 & 436 & 9,11 & 27 & 22 \\
\hline \multicolumn{2}{|c|}{ TOTAL } & 71.004 & 63.903 & 7.101 & 10,00 & 408 & 304 \\
\hline
\end{tabular}

Source: Social Service, Women Empowerment and Family Planning Kab. Rembang

Data from the Office of Social Affairs, Women's Empowerment and Family Planning in Rembang Regency explains that the quota of Non-Cash Food Assistance Beneficiaries (KPM) in June 2019 was 71,004 KPM, but of this total only 63,903 KPM or $90.00 \%$ had already received a Prosperous Family Card (KKS) and made transactions in E-warong while 7,101 families or as much as $10.00 \%$ had not received a Prosperous Family Card (KKS) and had not made transactions as a condition for taking BPNT. The causes of the non-distribution of KKS include duplicate data, 
Melly Anggraeni, Hardi Warsono, Ida Hayu Dwimawanti; Management of Distribution ... $\mid 487$

a single KPM candidate dies, a KPM candidate does not want to take it, a KPM candidate resigns because he is a well-off family, moves to another Regency / City, an unknown KPM candidate, an unprinted KKS and KKS has not been activated by the channeling bank. This shows that there is a lack of coordination between implementers from the district to village level so that there is no updating of data which causes the distribution of BNPT to experience problems due to changes in data that do not match those in the field.

Based on the direction of the Head of Sub-Directorate for Regional Assistance 2 of the Ministry of Social Affairs of the Republic of Indonesia at the time of Technical Guidance for District Social Welfare Workers (TKSK), the welfare family card (KKS) that has not been distributed is not filled with balances. This creates a dilemma for TKSK that has distributed and or notified the village that the KKS is brought by TKSK and can be retrieved by completing the required requirements.

\section{Control (Control) in Distribution of Non-Cash Food Aid in Rembang Regency.}

In management, supervision is the final stage for monitoring, evaluating all organizational activities whether they are in accordance with the established plan. Supervision in the management of Non-Cash Food Aid Distribution can be used as a tool to see whether the performance of BPNT program management is in accordance with the established guidelines or technical guidelines.

In connection with the supervision of the distribution of BPNT in Rembang Regency, Central Java Province, the February 2019 period is over for KKS that do not experience problems (KKS that can be swiped). For the March 2019 period, on March 20, 2019, the balance has not yet been entered in the KPM account. To date, 6 Districts have completed distribution for the March period and one District has begun dropping preparations for April 2019, the other 8 Districts have started dropping preparations for the March 2019 period. Some of the challenges experienced in implementing BPNT in Rembang Regency include:

1. The schedule for distributing KKS for October 2018 (which starts on 20-29 October 2018) has not been carried out well because many Village Heads refuse so they want to not bring KPM. Then it is rescheduled in November 2018 which is still ongoing until December 2018. Currently there are KKS in BNI.

2. Almost all sub-districts have not yet fully fulfilled the EDC swipe tool from BNI, so it is necessary to accelerate the fulfillment of EDC.

3. KKS found that transactions cannot be used, errors and balances are 0 .

4. Reports from Warong Agents on KPM that did not enter BPNT's balance in February March and April 2019.

\section{CONCLUSION}

Non-Cash Food Assistance is food assistance from the government that is given to KPM every month through an Electronic account mechanism which is used only to buy food items at foodstuff traders in collaboration with Bank Himbara / E Warung Kube PKH which aims to reduce the expense burden and provide nutrition more balanced to KPM on target. In the implementation of the distribution of non-cash food aid in Rembang Regency, there are still 


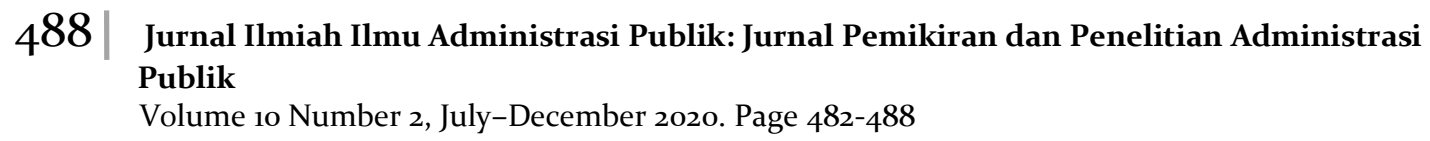

several obstacles related to its management, including: there are still many people who have not received a welfare family card, there has been no update of the latest data regarding program beneficiaries. Another problem in management is that planning needs to be planned and identified by potential beneficiary communities so that they are right on target and the need for regular outreach to the community so that they understand the mechanisms for distributing assistance, lack of coordination between the implementing team at the district to village level so that there is an error in name verification. beneficiaries, and the lack of supervision from program facilitators, so that there are many findings of errors in the field in the mechanism for distributing Non-Cash Food Assistance.

\section{REFERENCE}

Hasibuan Malayu S.P. (2009). Manajemen: dasar, Pengertian, dan Masalah Edisi Revisi. Jakarta: Bumi Aksara.

Mayang Shahira Junaidi, Bambang Mulyatno Setiawan dan Wahyu Dyah Prastiwi. 2017. The Satisfaction Comparison Of Bantuan Pangan Non Tunai Recipients And Rastra Recipients in Cakung District, East Jakarta. Jurnal Ilmiah Econosains Vol.15 No. 2

Miles, M.B, Huberman, A.M, dan Saldana, J. (2014). Qualitative Data Analysis, A Methods Sourcebook Edition 3. USA: Sage Publications.

Moeloeng, Lexy J. (2012). Metodologi Penelitian Kualitatif. Bandung: PT. Remaja Rosda Karya

Rachman, Benny, Adang Agustian dan Wahyudi. 2018. Efektivitas Dan Perspektif Pelaksanaan Program Beras Sejahtera (RASTRA) dan Bantuan Pangan Non Tunai (BPNT). Jurnal Analis Kebijakan Pertanian, Vol. 16 No. 1, Juni 2018: 1-18.

Ramadhan, Tondi. 2018. Efektivitas Program Bantuan Pangan Non Tunai Terhadap Peningkatan Kesejahteraan Masyarakat Kecamatan Tampan Pekanbaru. JOM FISIP Vol. 5 Edisi II Juli - Desember 2018.

Risnandar dan Aditya Wisnu Broto. 2018. Implementasi Program Bantuan Sosial Non Tunai Di Indonesia. Sosio Konsepsia Vol. 7, No.03.

Tim Pengendali Pelaksanaan Penyaluran Bantuan Sosial Secara Non Tunai Kementerian Koordinator Bidang Pembangunan Manusia Dan Kebudayaan Manusia. 2017. Pedoman Umum Bantuan Pangan Non Tunai. Jakarta

Sugiyono. (2015). Metode Penelitian Kuantitatif Kualitatif dan R\&D. Bandung: Alfabeta 